\title{
Efek Sedativa dan Kebugaran Teh Celup Daun Gaharu (Aquilaria malaccensis $L$ )
}

Penulis

Afiliasi

\author{
Muhammad Totong Kamaluddin ${ }^{1}{ }^{*}$, Yuliarni $^{1}$, Yeni Agustin ${ }^{1}$, Nita Parisa ${ }^{1}$, Rahmat Hidayat ${ }^{1}$, Tri \\ Wahyuni $^{2}$, Citra Yuliana ${ }^{2}$, Perryanis ${ }^{2}$
}

${ }^{1}$ Bagian Farmakologi Fakultas Kedokteran, Universitas Sriwijaya

${ }^{2}$ Pemerintah Kabupaten Bangka Tengah, Provinsi Bangka Belitung

\section{Kata Kunci}

- Teh Gaharu (Aquilaria malaccensis)

$\rightarrow$ Rasa kantuk

$\rightarrow$ Hormon seks

P Hepatotoksik

Diterima 15 Juni 2017 Direvisi 30 Agustus 2017 Disetujui 10 November 2017

*Penulis Koresponding Muhammad Totong Kamaluddin Bagian Farmakologi, Fakultas Kedokteran Unsri, Jl.

Dr.Moh.Ali Kompl. RSUP Mohd Hoesin, Palembang

totongkamaluddin@unsri.ac.id

\section{ABSTRACT}

Daun Gaharu (Aquilaria malaccensis) sejak lama telah digunakan masyarakat Kabupaten Bangka Tengah untuk menangkal keletihan akibat gangguan tidur ringan. Minuman yang diramu dari daun Gaharu yang diiris-iris lalu dijemur sebentar kemudian disedu air hangat kuku ternyata berkhasiat untuk menimbulkan rasa kantuk dan setelah bangun dari terlelap sejenak maka tubuh akan menjadi lebih segar. Penelitian ini ingin membuktikan manfaat tersebut di atas. Sejumlah 60 orang sukarelawan sehat terdiri dari 30 orang laki-laki dan 30 orang wanita dengan rentang umur 18 - 60 tahun berpartisipasi untuk membuktikan efek sedativa dan pengaruh kesehatan lainnya. Dengan disain pre-post test serta kerelaan sukarelawan sehat ini (dengan mengisi informed consent) sebagai responden, maka semuanya diberi minum teh celup Gaharu yang berisi $1 \mathrm{~g}$ simplisia kering/saset setiap hari selama 3 minggu berturut-turut. Setelah selesai satu sesi minum, semuanya diwawancarai pemeriksaan fisik, mental dengan menggunakan kuesioner model Pittsburgh Insomnia Rating Scale (PIRS) serta dikoleksi darah intravenanya. Hasil menunjukkan bahwa $32 \%$ responden timbul rasa kantuk ringan, $10 \%$ merasa lebih segar walaupun terasa sakit kepala ringan, serta berkurangnya rasa pegal dan nyeri sendi namun nafsu makan bertambah. Profil darah rutin tidak berubah namun kadar hormon seks seperti testosteron, progesteron, estradiol dan FSH meningkat ringan tanpa LH serta penurunan fibrinogen dan hs-CRP. Sedangkan transaminase hepar tidak berubah. Dari temuan ini disimpulkan bahwa konsumsi rutin teh gaharu memperbaiki profil tidur dan kesegaran jasmani namun tidak bersifat hepatotoksik. Perubahan kadar hormon seks, fibrinogen dan hs-CRP perlu dikaji lebih lanjut.

\section{PENDAHULUAN}

Tumbuhan Gaharu (Aquilaria malaccensis) yang tumbuh subur dinegara tropis termasuk di Indonesia dikenal dengan nama Agarwood, Eaglewood, Aloewood, Lignaloes (Huda et al. 2009; Pranakhon et al. 2010; Jiang et al. 2011). Tumbuhan ini sejenis

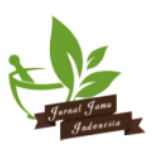


pohon dari suku gaharu-gaharuan (Thymelaeaceae) yang dijumpai secara luas baik sebagai tumbuhan hutan atau hasil budi daya masyarakat di Bangladesh, Bhutan, India, Indonesia, Iran, Laos, Malaysia, Myanmar, Filipina, Singapura dan Thailand. Di Indonesia, tumbuhan ini banyak ditemukan di Sumatera, Bangka, dan Kalimantan.

Batang pohon Gaharu adalah sumber utama gaharu (agarwood), suatu produk berbentuk kayu dengan resin beraroma wangi yang dipakai sebagai campuran parfum dan setanggi. Produksi resin ini timbul karena dirangsang oleh infeksi parasit kapang dari genus Ascomycetes (Pheaoacremonium parasitica) yang berdinding sel gelap. Selain itu daun tumbuhan Gaharu telah dimanfaatkan pula oleh sebagian masyarakat untuk minuman teh yang dapat menyegarkan tubuh serta menambah semangat kerja.

Masyarakat pedesaan telah mengenal khasiat daun Gaharu untuk "minuman teh keluarga" secara tradisional dan dikenal sebagai teh herbal (Kamaluddin et al. 2012). Khasiat teh daun Gaharu pada manusia belum diteliti secara ilmiah. Idealnya suatu minuman teh yang diproduksi dari herbal memberikan efek untuk meningkatkan mutu kesehatan serta mudah dikonsumsi seperti produk teh celup (Subroto 2006). Selain itu teh herbal diharapkan berkhasiat untuk membantu penyembuhan berbagai penyakit seperti mencegah/mengurangi penyakit jantung dan kanker, mengurangi resiko penyakit Diabetes Mellitus (penyakit gula), mengurangi resiko penyakit darah meninggi, penyakit kolesterol dan asam urat, memperbaiki pencernaan, menghaluskan kulit, melangsingkan tubuh dan memperlambat proses penuaan (Suharmiati 2003; Tjay dan Rahardjo 2007). Beberapa teh herbal yang dikenal saat ini seperti Green Tea merupakan ramuan beberapa herbal berkhasiat dengan kandungan antioksidan yang berkualitas sehingga mampu menyehatkan dan menyegarkan badan serta mempercepat penyembuhan suatu penyakit.

Masyarakat Bangka Tengah secara empiris telah mengkonsumsi teh dari daun Gaharu untuk menyegarkan badan, menurunkan kadar gula darah dan kolesterol serta menjadi nyaman dan nyenyak tidur. Namun demikian, data-data kesehatan tersebut belum didukung dari hasil penelitian ilmiah dan meyakinkan. Penelitian ini bertujuan untuk menilai manfaat kesehatan teh daun gaharu pada manusia dengan cara mengumpulkan data-data dari sukarelawan sehat agar diperoleh suatu hasil analisis kesehatan menyeluruh, baik perubahan fisik dan mental serta data laboratorium yang mendukung khasiatnya tersebut.

\section{METODE}

Penelitian ini adalah penelitian Uji Klinik Fase I prepost test design. Lama penelitian 5 bulan. Uji klinik ini layak dilakukan karena sudah diperoleh data uji keamanan preklinik pada tikus dengan $\mathrm{LD}_{50}$ pada tikus Wistar (Rattus norvegicus) adalah $3.852 \mathrm{~g} / \mathrm{kg}$ BB. Konversi dosis pada manusia adalah $616.32 \mathrm{mg} / \mathrm{kgBB}$. Dosis ini termasuk golongan toksisitas ringan (Kamaluddin et al. 2012). Selain itu penelitian ini sudah memperoleh sertifikat kelayakan etik dari tim Ethical Clearance Fakultas Kedokteran Universitas Sriwijaya.

Responden adalah manusia sukarelawan sehat yang bersedia mengikuti penelitian dengan mengisi informed consent, rentang umur 18-60 tahun, jumlah responden 30 orang laki-laki dan 30 orang wanita, tidak cacat fiisik dan mental.

Bahan uji adalah teh celup daun Gaharu terstandar yang mengandung $1 \mathrm{~g}$ bubuk kering daun Gaharu, diperoleh dari produksi tim peneliti teknologi pangan Lembaga Penelitian Unsri.

Seminggu sebelum penelitian dimulai setiap responden terpilih tidak boleh mengkonsumsi teh celup merk apapun dan atau obat-obatan. Kemudian setiap responden terpilih diperiksa pada hari (0) sebelum penelitian dan setelah selesai minum rutin setiap hari selama 21 hari (hari ke 22) keadaan fisik dan mentalnya dinilai menurut diagram kuesioner Pittsburgh Insomnia Rating Scale (PIRS) (Moul et al. 2002). Demikian pula data laboratorium yang diambil dari darah vena kubiti dilakukan oleh tim petugas Balai Besar Laboratorium Kesehatan (BBLK) Palembang sesuai SNI ISO 15189-2012 sertifikat KAN LP.233-ICN. Selain itu diperiksa pula kesehatan standar fisik oleh dokter peneliti lapangan tentang : keadaan umum, tekanan darah dan denyut nadi, irama dan jumlah pernapasan, auskultasi irama jantung, pernapasan, dan bising usus, kemudian diukur berat badan (BB kg), tinggi badan $(T B \mathrm{~cm})$ serta nilai gizi (ukuran lingkaran lengan atas). Setiap responden diawasi oleh petugas peneliti lapangan untuk pembuktian minum bahan penelitian secara benar. Semua data terkumpul dari pre- and post test direkam dan dianalisis secara akurat dengan ANOVA dan paired t-test serta dinilai kemaknaannya pada $\alpha<0.05$. 


\section{HASIL DAN PEMBAHASAN}

Sebaran umur dan jenis kelamin dari 60 responden sukarelawan sehat yang diikutsertakan dalam penelitian ini dapat dilihat pada Tabel 1. Semua responden mendapat perlakuan yang sama. Guna memperoleh informasi lengkap dari kondisi fisik semua responden tentang tanda-tanda vital seperti tekanan darah, denyut nadi, laju pernapasan, suhu tubuh, keadaan kepala, dada, perut dan ekstremitas dapat dilihat pada Tabel 2. Demikian pula hasil pemeriksaan mental menurut skala PIRS, konsep "Insomnia Rating Scale" sesudah perlakuan nilainya menurun, sementara sensasi mengantuk dirasakan oleh $31.67 \%$ responden, walaupun hanya $1.67 \%$ justru sulit tidur, berkurangnya nyeri sendi dan sakit kepala ringan dirasakan oleh
$11.67 \%$ responden, merasa lebih bugar setelah terlelap tidur sebentar dirasakan oleh $10 \%$ responden dan bahkan bertambah napsu makannya dirasakan oleh $8.33 \%$ responden.

Tabel 1 Sosiodemografi responden $(n=60)$

\begin{tabular}{lcc} 
No. & Data Sosiodemografi & Jumlah \\
\hline 1. & Umur : & \\
& $\bullet \quad 20-30$ tahun (\%) & 33.33 \\
& $\bullet \quad 31-40$ tahun (\%) & 33.33 \\
& $\bullet \quad>40$ tahun (\%) & 33.33 \\
2. & Jenis Kelamin : & \\
& $\bullet \quad$ Laki-laki (\%) & 46.67 \\
& $\bullet \quad$ Perempuan (\%) & 53.33 \\
\hline
\end{tabular}

Tabel 2 Hasil wawancara dan pemeriksaan fisik responden $(n=60)$

\begin{tabular}{|c|c|c|c|}
\hline No. & Pemeriksaan & Sebelum Perlakuan & Sesudah Perlakuan \\
\hline \multirow[t]{11}{*}{1.} & Wawancara: & & \\
\hline & Sensasi yang dirasakan (\%) & & \\
\hline & Mengantuk & 0 & 31.67 \\
\hline & Nyeri sendi berkurang & 0 & 11.67 \\
\hline & Peningkatan nafsu makan & 0 & 8.33 \\
\hline & Segar bugar & 0 & 10.00 \\
\hline & Diare & 0 & 6.67 \\
\hline & Sakit kepala ringan & 0 & 11.67 \\
\hline & Gatal & 0 & 3.33 \\
\hline & Sulit tidur & 0 & 1.67 \\
\hline & Sakit perut & 0 & 1.67 \\
\hline \multirow[t]{6}{*}{2.} & Tanda Vital : & & \\
\hline & Tekanan darah sistolik (mmHg) & 115 & 112 \\
\hline & Tekanan darah diastolik (mmHg) & 75 & 73 \\
\hline & Nadi (kali/menit) & 80 & 80 \\
\hline & Laju pernafasan (kali/menit) & 20 & 20 \\
\hline & Suhu $\left({ }^{\circ} \mathrm{C}\right)$ & 36.7 & 36.8 \\
\hline \multirow[t]{3}{*}{3.} & Pemeriksaan Fisik Kepala \&Leher : & & \\
\hline & Normal (\%) & 100 & 100 \\
\hline & Tidak normal (\%) & 0 & 0 \\
\hline \multirow[t]{3}{*}{4.} & Pemeriksaan Fisik Dada : & & \\
\hline & Normal (\%) & 100 & 100 \\
\hline & Tidak normal (\%) & 0 & 0 \\
\hline \multirow[t]{3}{*}{5.} & Pemeriksaan Fisik Perut : & & \\
\hline & Normal (\%) & 100 & 100 \\
\hline & Tidak normal (\%) & 0 & 0 \\
\hline \multirow[t]{3}{*}{7.} & Pemeriksaan Fisik Ekskremitas : & & \\
\hline & Normal (\%) & 100 & 100 \\
\hline & Tidak normal (\%) & 0 & 0 \\
\hline 8. & Pemeriksaan : Insomnia Rating Scale & 4 & 2 \\
\hline
\end{tabular}


Data pemeriksaan mental diperoleh dari hasil wawancara kepada setiap responden dengan mengacu pada kuesioner yang ingin menggali tentang lama tidur, mimpi, kualitas tidur, waktu keinginan untuk tidur, bangun malam hari, rasa ingin tidur kembali, serta rasa segar setelah bangun tidur. Selain itu ditanyakan pula perasaan tentang kualitas hidup, dan kesehatan menurut panduan "Whoqol-Bref" yang berisi pertanyaan kualitas hidup, kepuasan terhadap kesehatan yang dirasakan saat ini, rasa sakit dan nyeri, kebutuhan tenaga kesehatan, nikmat hidup, konsentrasi, kesehatan lingkungan, vitalitas untuk beraktivitas, serta penerimaan penampilan dirinya sendiri dengan skoring masing-masing sangat buruk, buruk, biasa-biasa saja, baik dan sangat baik (WHO 1997). Dari Tabel 2 ternyata $10 \%$ dari semua responden menyatakan perubahan nyata yang dirasakan positif dari butir pertanyaan dan diskusi di atas. Setelah wawancara dilanjutkan dengan pemeriksaan laboratorium darah yang menunjukkan peningkatan nilai Laju Endap Darah (LED), sedangkan kadar Hemoglobin, jumlah eritrosit, lekosit, hematokrit dan trombosit tidak berubah (Tabel 3). Sebaliknya pada pemeriksaan kimia darah responden terjadi peningkatan ringan kadar kolesterol, HDL, SGOT, SGPT, namun terjadi penurunan kadar fibrinogen dan hs-CRP. Kadar LDL, trigliserida, gula darah dan $\mathrm{Hb}_{\mathrm{Alc}}$ tidak mengalami perubahan (Tabel 4). Hasil pemeriksaan hormon seks semua responden diperoleh peningkatan FSH, progesteron, testosteron dan estradiol, sedangkan LH dan prolaktin tidak berubah (Tabel 5).

Semua responden yang diteliti memiliki ciri distribusi normal, oleh karena itu maka data-data yang diperoleh dapat dibandingkan. Hasil pemeriksaan darah rutin pada responden masih dalam batas normal, tidak ada perbedaan bermakna dari kadar hemoglobin, jumlah eritrosit, leukosit, hematokrit serta trombosit antara subyek sebelum dan sesudah mengkonsumsi teh Gaharu selama 21 hari. Sedangkan nilai LED, didapatkan peningkatan walaupun nilainya masih dalam batas normal, hal ini diduga karena terjadi perubahan kadar hormon seks dan timbulnya keseimbangan baru dari air dan elektrolit dalam tubuh. Kandungan berbagai polifenol daun Gaharu terutama mangiferin dan genkwanin 5-O- $\beta$-primeveroside (Ito et al. 2012) sebagai komponen bioaktif diduga berperan menimbulkan efek antioksidan serta rasa bugar setelah terlelap sejenak dari $31.67 \%$ responden dengan menstabilkan sistem hematopoeitik dan interaksi beberapa neurotransmiter otak. Selain itu

Tabel 3 Hasil pemeriksaan rerata darah rutin responden $(n=60)$

\begin{tabular}{clcc} 
No. & \multicolumn{1}{c}{ Darah Rutin } & Kadar Sebelum Perlakuan & Kadar Setelah Perlakuan \\
\hline 1. & Hemoglobin $(\mathrm{g} / \mathrm{dl})$ & 13.36 & $13.27^{* *}$ \\
2. & LED (mm/jam) & 11.53 & $13.62^{*}$ \\
3. & Erirosit & 4.8 juta & 4.76 juta** \\
4. & Leukosit & 7813 & $7700^{* *}$ \\
5. & Hematokrit & 39.66 & $39.42^{* *}$ \\
6. & Trombosit & 299466 & $298416^{* *}$ \\
\hline
\end{tabular}

${ }^{*} p<0.05$, Uji T test dependent, ${ }^{* *} p>0.05$, Uji T test dependent

Tabel 4 Kadar rerata kimia darah responden $(n=60)$

\begin{tabular}{clcc}
\hline No. & \multicolumn{1}{c}{ Kimia Klinik } & Kadar Sebelum Perlakuan & Kadar Setelah Perlakuan \\
\hline 1. & Kolesterol $(\mathrm{mg} / \mathrm{dl})$ & 130.28 & $131.18^{*}$ \\
2. & HDL $(\mathrm{mg} / \mathrm{dl})$ & 41.78 & $42.50^{*}$ \\
3. & LDL $(\mathrm{mg} / \mathrm{dl})$ & 88.68 & $88.48^{* *}$ \\
4. & Trigliserida $(\mathrm{mg} / \mathrm{dl})$ & 114.96 & $114.68^{* *}$ \\
5. & Gula darah $(\mathrm{mg} / \mathrm{dl})$ & 100.46 & $103.23^{* *}$ \\
6. & SGOT & 24.46 & $25.31^{*}$ \\
7. & SGPT & 23.47 & $24.19^{*}$ \\
8. & Fibrinogen $(\mathrm{ng} / \mathrm{dl})$ & 42.22 & $38.34^{*}$ \\
9. & Hb & 3.79 & $3.76^{* *}$ \\
10. & hs-CRP $(\mathrm{mg} / \mathrm{dl})$ & 0.52 & $0.44^{*}$ \\
\hline
\end{tabular}

$* \mathrm{p}<0.05, \mathrm{Uji}$ T test dependent, ${ }^{* *} \mathrm{p}>0.05, \mathrm{Uji} \mathrm{T}$ test dependent 
Tabel 5 Perubahan kadar hormon seks semua responden $(n=60)$

\begin{tabular}{clcc} 
No. & \multicolumn{1}{c}{ Hormon } & $\begin{array}{c}\text { Kadar Hormon Sebelum } \\
\text { Perlakuan }\end{array}$ & $\begin{array}{c}\text { Kadar Hormon Setelah } \\
\text { Perlakuan }\end{array}$ \\
\hline 1. & FSH $(\mathrm{mlU} / \mathrm{ml})$ & 7.74 & $8.06^{*}$ \\
2. & LH $(\mathrm{mlU} / \mathrm{ml})$ & 7.44 & $7.44^{* *}$ \\
3. & Progesteron $(\mathrm{ng} / \mathrm{ml})$ & 1.98 & $2.26^{*}$ \\
4. & Testosteron $(\mathrm{ng} / \mathrm{ml})$ & 1.57 & $2.44^{*}$ \\
5. & Prolactin $(\mathrm{ng} / \mathrm{ml})$ & 2.71 & $2.71^{* *}$ \\
6. & Estradiol $(\mathrm{pg} / \mathrm{ml})$ & 15.41 & $16.56^{*}$ \\
\hline
\end{tabular}

${ }^{*} p<0.05$, Uji T test dependent, ${ }^{* *} p>0.05$, Uji T test dependent

meningkatnya kadar estrogen, testosteron dan progesteron akan menimbulkan efek segar setelah berlalu efek kantuk, namun data kadar adrenalin, melatonin, kortisol, ghrelin dan leptin yang turut berperan untuk menimbulkan rasa kantuk tidak diperiksa. Besaran aktivitas neurotransmisi sentral dari fungsi otak menentukan rasa kantuk.

Perubahan profil lipid kolesterol total, dan HDL, enzim hati (SGOT dan SGPT), kecuali LDL, dan trigliserida, gula darah mendukung pula efek bugar, namun penurunan kadar fibrinogen, $\mathrm{Hb}_{\mathrm{Alc}}$ dan hs-CRP yang diduga menimbulkan efek berkurangnya rasa nyeri sendi sehingga menambah keleluasaan fisik bergerak turut menambah kebugaran. Kemudian tidak meningkatnya kadar transaminase dalam darah dapat diduga bahwa teh Gaharu tidak bersifat hepatotoksik (Ngatijan 2006). Peningkatan enzim hati merupakan penanda terjadinya gangguan dalam keutuhan dan integritas sel hati. Akan tetapi, peningkatan yang terjadi pada sebagian responden masih dalam batas normal. Namun demikian, tetap perlu dilakukan studi dan pemantauan dosis pemberian teh Gaharu agar tidak menyebabkan gangguan fungsi hati yang serius. Penurunan kadar fibrinogen menyebabkan penurunan kekentalan darah sehingga diduga bermanfaat dalam mengurangi risiko terjadinya sumbatan pembuluh darah akibat pembentukan bekuan darah (trombogenesis). Penyumbatan bekuan darah merupakan salah satu penyebab utama terjadinya kondisi aterosklerosis yang dapat berakhir dengan penyakit kardiovaskuler, serangan jantung dan stroke. Penurunan kadar CRP menunjukkan penurunan respon inflamasi antara lain ditandai dengan berkurangnya rasa nyeri sendi-sendi. Respon inflamasi berperan dalam menginisiasi terjadinya stress oksidatif dan peningkatan radikal bebas yang berujung pada peningkatan kejadian penyakit-penyakit degeneratif seperti diabetes, dislipidemia ataupun penyakit kardiovaskular lainnya, sehingga dengan berkurangnya respon inflamasi maka akan mengurangi terbentuknya radikal bebas dan olaeh sebab itu mampu mencegah beratnya penyakit degeneratif (Abram et al. 2009; Huda et al. 2009; Katzung 2009; Jiang et al. 2011).

Penurunan kadar gula tidak berbeda bermakna secara statistik dibandingkan dengan sebelum pemberian, hasil ini bertentangan dengan temuan Pranakhon et al. 2010 yang menilainya pada subjek model diabetes. Sebenarnya perubahan kadar gula dan $\mathrm{Hb}_{\mathrm{A} 1 \mathrm{c}}$ mulai terjadi jika minum ekstrak air daun Gaharu selama 3 bulan berturut-turut (Tjay et al. 2007; Pranakhon et al. 2010). Sedangkan minum teh Gaharu hanya 3 minggu ternyata tidak merubah dan menurunkan kadar gula darah. Peningkatan kadar HDL pada penelitian ini cukup berarti dan berperan dalam memproteksi tubuh dari gangguan-ganguan degeneratif. Peningkatan kadar HDL pada subyek penelitian menunjukkan bahwa teh gaharu memiliki potensi dalam memproteksi tubuh dari gangguangangguan degeneratif. Diduga efek protektif ini diperoleh setelah minum teh Gaharu jangka panjang.

\section{SIMPULAN}

Melihat Minum teh Gaharu setiap hari selama 3 minggu berturut-turut memperbaiki pola tidur (efek sedativa), istirahat dan setelah bangun badan terasa lebih segar serta bergairah untuk melakukan aktivitas fisik kembali. Selama mengkonsumsi teh Gaharu tidak nampak tanda-tanda gangguan fungsi hepar.

Diduga peningkatan gairah kerja fisik karena terjadinya peningkatan hormon seks, penurunan kadar fibrinogen serta hs-CRP yang masih perlu pembuktian dalam suatu penelitian lebih lanjut.

\section{UCAPAN TERIMA KASIH}

Tim peneliti mengucapkan terima kasih atas dukungan serta bantuan dana dan fasilitas penuh dari

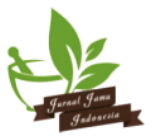


Pemerintah Kabupaten Bangka Tengah Provinsi Bangka Belitung melalui Lembaga Penelitian Universitas Sriwijaya.

\section{DAFTAR PUSTAKA}

Abram AC, Sandra SP, Carol BL. 2009. Clinical Drug Therapy. Rationale for Nursing Practice. $9^{\text {th }}$. Philadelphia (PA): Lippincott Williams and Wilkins.

Darmono. 2007. Pola Hidup Sehat Penderita Diabetes Mellitus. Dalam: Naskah lengkap diabetes mellitus ditinjau dari berbagai aspek penyakit dalam. Darmono, Suhartono T, Pemayun TGD, Padmomartono FS, editor. Semarang (ID): Badan Penerbit Universitas Diponegoro.

Djojosoebagio. 2007. Fisiologi kelenjar endokrin. Jakarta (ID): Penerbit UI-Press,

Goodman, Gillman's. 2005. The Pharmocological Basis of Therapeutics. Edisi 11. New York (NY): McGRAWHILL. Medical Publishing division.

Huda AWN, Munira MAS, Fitrya SD, Salmah M. 2009. Antioxidant activity of Aquilaria malaccensis (Thylmelaeaceae) leaves. Pharmacognosy Research. 1(5):270-273.

Ito $T$, Kakino $M$, Tazawa S, Watarai $T$, Oyama $M$, Maruyama H, Araki Y, Hara H, Linuma M. 2012. Quantification of Polyphenols and Pharmacology Analysis of Water and Ethanol-based Extracts of Cultivated Agarwood Leaves. Journal of Nutritional Science and Vitaminology. 58:136-142.

Jiang S, Jiang Y, Guan YF, Tu PF, Wang KY, Chen JM. 2011. Effects of $95 \%$ ethanol extract of Aquilaria sinensis leaves on hyperglycemia in diabetic $\mathrm{db} / \mathrm{db}$ mice. Journal of Chinese Pharmaceutical Sciences. 20(6):609-614.

Kamaluddin MT, Saleh I, Yeni A. 2012. Laporan Penelitian Preklinik Simposia daun Gaharu pada tikus putih galur Wistar. Sponsor Pemda Bateng.

Katzung BG. 2009. Basic And Clinical Pharmacology, $10^{\text {th }}$ Edition, The McGraw-Hill Companies, International Edition, Singapore.

Lee MS, Thuong PT. 2010. Stimulation of glucose uptake by triterpenoids from Weigela. Subsessilis. Phytoterapy Research.
Moul DE, Pilkonis PA, Miewald JM, Carey TJ, Buysse DJ. 2002. Preliminary study of the test-retest reliability and concurrent validities of the Pittsburgh Insomnia Rating Scale (PIRS). Sleep 25 Abstract Supplement, A246-A247.

Murray RK, Granner DK, Mayes PA, Rodwel VW. 2003. Biokimia harper. Ed.25. Terjemahan dari Harper's biochemistry, oleh Andry $\mathrm{H}$, penerjemah. Jakarta (ID): Penerbit Buku Kedokteran EGC.

Nakanishi T, Yamagata E, Yoneda K, Miura I, Jinkohol. 1981. A prezizane sesquiterpene alcohol from agarwood. Phytochemistry. 20:1597-99.

Ngatidjan. 2006. Metode Laboratorium dalam Toksikologi. Yogyakarta (ID): Bagian Farmakologi dan Toksikologi Fakultas Kedokteran UGM.

Pranakhon R, Pannangpetch P, Aromdee C. 2010. Antihyperglikemic activity of agaarwood leaf extracts in STZ-induced diabetic rats and glucose uptake enhancement activity in rat adipocytes. Songklanakarin Journal of Science and Technology. 33(4):405-410.

[PERKENI] Perkumpulan Endokrinologi Indonesia. 2006. Konsensus pengelolaan dan pencegahan diabetes melitus tipe 2 di Indonesia. PERKENI.

Riset Kesehatan Dasar. 2007. Badan Penelitian dan Pengembangan Kesehatan. Diambil tanggal 4 Juli 2012

http://www.riskesdas.litbang.depkes.go.id/2010

Subroto MA. 2006. Ramuan Herbal untuk Diabetes Mellitus. Jakarta (ID): Penebar Swadaya.

Sugiwati S. 2005. Aktivitas Antihiperglikemik dari Ekstrak Buah Mahkota Dewa [Phaleria macrocarpa (Scheff.) Boerl.] sebagai Inhibitor Alfa Glukosidase in vitro dan in vivo pada Tikus Putih [tesis]. Bogor (ID): Sekolah Pascasarjana Institut Pertanian Bogor.

Suharmiati. 2003. Pengujian Bioaktivitas Antidiabetes Melitus Tumbuhan Obat. Cermin Dunia Kedokteran. 140:8-9.

Tjay TH, Rahardjo K. 2007. Obat-Obat Penting: Khasiat Penggunaan dan Efek-Efek Sampingnya, Edisi ke VI. Jakarta (ID): PT. Elek Media Komputindo.

[WHO] World Health Organization. 1997. WHOQOL Group, Programme on Mental Health, Field Trial Version. Switzerland (SY): CH-1211 Geneva 27. 